\title{
Developing Google Classroom Based Learning Media for Patisserie Subject to Improve Students' Learning Outcomes in Culinary Art Education Unimed
}

\author{
Yuspa Hanum ${ }^{1}$, Nila Handayani ${ }^{2}$, Mastarina Barus ${ }^{3}$, Erli Mutiara ${ }^{4}$ \\ \{yuspa_hanum@yahoo.com ${ }^{1}$, nilateguh@yahoo.co.id ${ }^{2}$, mastarinabarus@yahoo.co.id ${ }^{3}$, \\ erli_mutiara@yahoo.co.id ${ }^{4}$ \} \\ Department of Family Welfare Education, Faculty of Engineering, Universitas Negeri Medan, Medan, \\ Indonesia ${ }^{1,2,3,4}$ \\ yuspa_hanum@yahoo.com
}

\begin{abstract}
The purpose of this study is to develop google classroom learning media in patisserie subject. The type of this study is Research and Development (R\&D). The location of this study is in Culinary Art Program Study, Faculty of Engineering, Universitas Negeri Medan. This study was conducted from June-November 2019. Media validation for this subject consisted of 3 material experts, 3 media and design experts, and 22 students of Culinary Art Education Study Program as media users. The data collection techniques used the questionnaire. The data analysis technique is descriptive. Based on the results of this study according to the material expert validator based on the feasibility of the content obtained a value of $83 \%$ with good criteria, the presentation of material is $78 \%$ with good criteria and the language is $90 \%$ with very good. Based on the media validator, the presentation of the media is $90 \%$ with very good criteria, the media graphic is $94.44 \%$ with very good criteria, based on the material aspect user validator is $89.87 \%$ with good criteria, the media aspect display is $84.03 \%$ with very good criteria. The results of this study can be concluded that the google classroom media is good for learning media for the students of Culinary Art Study Program in Universitas Negeri Medan.
\end{abstract}

Keywords: Google Classroom, Media, Patisserie

\section{Introduction}

The education is currently growing; various kinds of updates are carried out in order to improve the quality and quantity of education. To improve the quality of education, various breakthroughs are needed both in curriculum development, learning innovation, and fulfillment of educational facilities and infrastructure. To improve the learning process, the lecturer is required to make learning more innovative which encourages students to learn optimally both in independent learning and in classroom learning [1].

The patisserie subject is one of the courses in the Culinary Art Education Study Program, in 
accordance with the KKNI curriculum. Patisserie is knowledge in food processing and serving, especially processing and serving various types of cakes. During this time, the lecturer just give an explanation before practice, and the students are required to study by the modules or practice the instructions by themselves.

Based on the observations, it was found that some students were not understood in practice. That makes the students can't finish their practice on time. When teaching in the class, the lecturer did not use learning media in the Patisserie subject. To make learning more interesting, it is necessary to use Google Classroom based learning media that can help students understand the material presented by lecturers and can communicate with lecturers if there are problems felt by students. And the students also can use these media independently in the outside class hours. If learning media is chosen, developed, used and utilized appropriately and well, it will provide enormous benefits in the teaching and learning process. Therefore, special attention needs to be paid to this learning media so that it can be used in the Culinary Education Study Program, because it is very helpful for lecturers and motivates students, and improves learning outcomes in learning both individually and in groups [2].

The development of technology and the internet in recent years has not only affected electronic products, but also in the education, especially learning methods. Maybe everyone was experienced sitting in a classroom with friends while the lecturer was explained the lesson in front of the class. This method is still applied today, but technological sophistication affects changes in teaching patterns. One of the technological developments in education is the emergence of Google Classroom that was officially released in August 2014. As the name implies, Google tries to 'move' the classroom to the online realm [3]. Google Classroom or in the Indonesian language that is Google Classroom is a mixed learning porch which is intended for each scope of education intended to find a way out of difficulties in making, sharing and classifying each assignment without paper. Utilization of Google classroom can be through multiplatform that can be through a computer and can through devices. Lecturers and students can visit the site https://classroom.google.com or can download the PlayStore application on Android or through the app store on iOS with the Google Classroom keyword [2]. The use is free of charge so that its utilization can be carried out as needed. The facilities available in e-learning based on Google Classroom to support learning are numerous, but in reality lecturers have not utilized internet-connected computer facilities for learning activities. Based on this, the researcher needs to do this with the title "Developing Google Classroom Based Learning Media for Patisserie Subject To Improve Students' Learning Outcomes in Culinary Art Education Unimed " The purpose of this study is to develop Google Classroom Based Learning Media.

\section{Research Method}

The design of this study is Research and Development (R\&D). The location of this study is in Culinary Art Program Study, Department of Family Welfare Education, Faculty of Engineering, Universitas Negeri Medan. This study was conducted from June-November 2019. Media validation for this subject consisted of 3 material experts, 3 media and design experts, and 22 students of Culinary Art Education Study Program as media users. The data collection techniques used the questionnaire. Data obtained through a questionnaire were analyzed using descriptive statistics. 


\section{Results and Discussion}

\section{a. Quality of Learning Materials.}

The quality of learning material on the google classroom learning media on Patisserie learning has 3 aspects assessed. The first aspect is about the appropriateness of the content, the second aspect is the evaluation of the presentation and the third aspect is the assessment of the language used in instructional media.

Based on the results of this study according to the material experts on the aspect of content eligibility including good criteria by 83.00 percent. Based on the answer to the appropriateness of the contents, namely the suitability and accuracy indicators of the material with a competency of 50 percent of respondents said that it was sufficient and 50 percent agreed strongly. On the indicator of the accuracy of the coverage of the material with a competency of 50 percent of respondents said it was enough and 50 percent of the respondents stated strongly agree. The suitability of the concept with each material tells the validation expert 50 percent strongly agree. In the depth indicator of learning material 50 percent of respondents stated that it was enough and 50 percent of respondents stated that they were very much in agreement. In the indicator of the suitability of the material with the curriculum by 50 percent agreed. The accuracy of the sequence of delivery of learning materials as much as 50 percent of respondents said that "Enough" and 50 percent of respondents said "Very Agree".

Based on the results of this study according to experts on the material aspects of presentation including good criteria by 78 percent. Based on the expert validation of the material, according to the presentation on the material indicators are presented simply and clearly as much as 50 percent of respondents expressed disagreement and 50 percent stated Strongly Agree. The material indicators are presented coherently, from simple to complex, 50 percent of material validation experts stated that it was sufficient and 50 percent agreed. On the indicator presentation of interactive material as much as 100 percent of respondents agreed. In the picture and material indicators as much as 50 percent of respondents agreed and 50 percent of respondents expressed strongly agree. In the time allocation indicator according to the need to learn as much as 50 percent of experts said that was enough and 50 percent agreed strongly. Based on the results of this study according to experts on the material aspects of language including very good criteria by 90 percent. Based on the material experts, linguistic aspects, namely the language indicator used is simple as many as 50 percent of respondents agreed and 50 percent stated strongly agree. In the indicator of material digestibility and logical exposure as much as 50 percent of respondents agreed and 50 percent stated strongly agree. In the indicator of the language used is easy to understand as much as 50 percent of respondents said agree and 50 percent expressed strongly agree.

\section{b. Quality Learning Design}

The quality of learning design on google classroom-based learning media on patisserie learning has 2 aspects of assessment. The first aspect is about presentation and the second aspect is the evaluation of graphics. 
Based on the results of this study according to media experts on the presentation aspects including very good criteria by 94.44 percent. Based on media experts on the presentation aspect, namely on the material indicators presented simply and clearly as much as 50 percent of experts stated agree and 50 percent expressed strongly agree. The material indicators are presented coherently, from simple to complex and from general to specific, as many as 50 percent of experts agreed and 50 percent strongly agreed. Interesting indicators "to study" as much as 100 percent of experts said they strongly agreed. Indicators of images and materials according to as much as 100 percent of experts stated strongly agree. Indicators of the use of different texts to mark important parts as much as 100 percent expressed strongly agree. On the indicator explanation of the term as much as 100 percent agree. In simple language indicators, 100 percent agree strongly. On the indicator of material digestibility and exposure 50 percent stated agreed and 50 percent of respondents stated strongly agree.

Based on the results of this study according to media experts on the graphic aspects including very good criteria by 90 percent. Based on the aspect of graphic that is the accuracy of the color composition indicator used as much as 50 percent of experts said agree and 50 percent expressed strongly agree. In the illustrated picture indicators according to the concept as much as 50 percent said they agreed 50 percent said they strongly agreed. "Easy to understand" indicators as much as 100 percent of respondents expressed strongly agree. The type and size indicator can be read as much as 50 percent of respondents agreed and 50 percent strongly agreed. Indicator of the comparison of letters between titles, subtitles, and manuscripts is proportional as much as 50 percent of respondents agreed and 50 percent strongly agreed. On the indicator of the accuracy of the selection of music and sound as much as 50 percent of respondents said it was enough and 50 percent agreed. In the indicators of "easy-to-use" showed as many as 100 percent of respondents stated strongly agree.

\section{c. Technical Quality and Display}

The technical quality and appearance of the google classroom-based learning media have 2 aspects of assessment conducted by students as media user respondents. Those aspects are the first aspect regarding the material and the second aspect of the assessment of the appearance of the media. Based on the results of this study according to users on material aspects including good criteria by 89.87 percent. Based on the material aspects of the suitability indicator and the accuracy of the material as much as 5 percent of respondents said it was enough, 18 percent agreed and 77 percent stated strongly agree. In the indicator of clarity of learning instructions as much as 5 percent of respondents said it was enough, 18 percent said they agreed and 77 percent said they strongly agreed. Indicators of ease of understanding sentences in the text as much as 9 percent of respondents said it was enough, 18 percent agreed and 73 percent stated strongly agree. Indicators of the accuracy of the order of presentation showed as much as 5 percent of respondents said it was enough, 50 percent said they agreed and 45 percent said they strongly agreed. Indicators of exercise adequacy as much as 5 percent of respondents said they disagree, 5 percent said it was enough, 63 percent said they agreed and 27 percent strongly agreed. On the indicator of clarity of feedback as much as 5 percent of respondents said it was enough, 50 percent said they agreed and 45 percent said they strongly agreed. On the indicator of ease of access as much as 5 percent of respondents said they disagree, 45 percent said they agree and 50 percent expressed strongly agree. 
Based on the results of this study according to the display aspects including good criteria by 84.03 percent. The distribution of respondents based on the display aspect is the indicator of the beauty of the color display as much as 5 percent of respondents said it was enough, 22 percent said they agreed and 73 percent said they strongly agreed. On the text readability indicator 18 percent of respondents stated that they disagree, 5 percent said it was enough, 23 percent said they agreed and 54 percent said they strongly agreed. Indicators of image quality and animation showed as much as 5 percent of respondents said it was enough, 27 percent said they agreed and 68 percent said they strongly agreed. The color composition indicator of 23 percent of respondents stated "Agree" and 77 percent stated strongly agree. Navigation Indicator as much as 10 percent of respondents said that it was enough, 45 percent said they agreed and 45 percent said they strongly agreed. On the music carrying capacity indicator as many as 14 percent of respondents said they did not agree, 45 percent said they disagreed, 9 percent said they were enough, 18 percent said they agreed and 14 percent strongly agreed. On the interaction indicator as much as 9 percent of respondents said they disagree, 14 percent said it was enough, 36 percent said they agreed and 41 percent said they strongly agreed.

\section{d. Results of Development Assessment Based Learning Media Google Classroom}

Based on the results of this study, the google classroom based learning media has 3 validation experts. The first assessment is based on material experts, the second is based on media experts and the third is based on user ratings. Developing Google Classroom Based Learning Media according to material experts obtained a value of $82.86 \%$ including good criteria. According to media experts, a value of 92.5 percent is included, including a very good criterion. According to the user, a value of 86.82 percent is included as a good criterion.

\section{e. Discussion of Research Results}

Google classroom learning media development is the development of learning material that has been developed by taking into account aspects of learning. Development research conducted to produce a product in the form of google classroom learning media used by students of the Catering Education at Medan State University that is used to improve students' learning processes.

The use of google classroom learning media allows students to more easily understand learning because of this learning media allows students to interact directly, so that each student has no difficulty imagining in reading because in this media has been explained in detail. In addition, this learning media is very practical because students can learn the material contained in this learning media at home or using laptops and cellphones or gadgets. This media can also test the ability and understanding of students directly through tests or questions, so students can find out the mistakes that have been made in working on the exercise questions. Aspects that are revised and refined based on data analysis and trials and input from material experts, media experts and users aim to explore some aspects that are prevalent in the process of developing a product. In Figure 1, it can be seen the average percentage of the results of the assessment of the google classroom learning media according to material experts, media experts and users.

In figure 1 it can be seen that the assessment based on the validation expert is material expert obtained a value of 82.86 percent including good criteria, according to media experts a value of 92.50 percent is included including very good criteria, according to the user obtained a value of 86.82 percent including good criteria. The results of this study are in accordance with the results of 
Wulansari's research [6] with the title Development of Learning Tools Based on Blended Learning Models by Utilizing Google Classroom in Vector Material in Three Dimensional Spaces in Class X MIA 4 of SMA Negeri 7 Yogyakarta. The results of this study indicate that the learning tools based on the blended learning model using google classroom on vector material are valid with excellent categories.

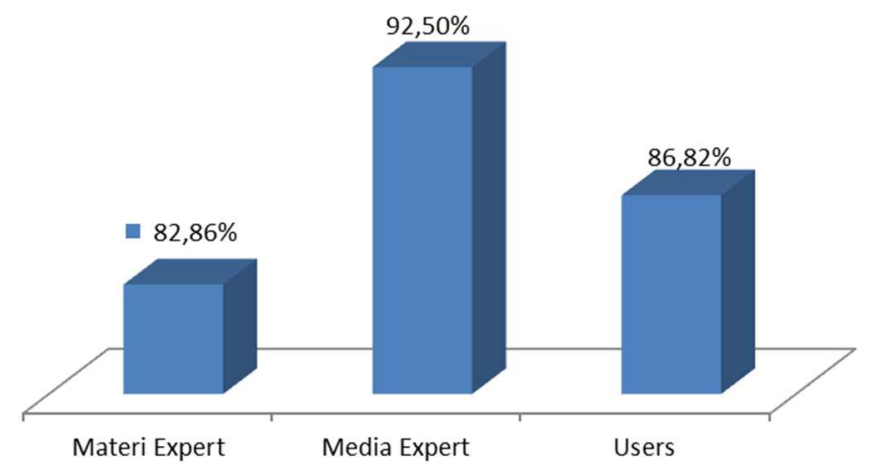

Figure 1. Expert and User validation results on Google classroom Learning Media

The results of this study are also in accordance with the results of Marasmita's research [4] with the title Development of Google Classroom-based E-Learning Learning Media to Increase Student Learning Motivation in Economics X Class Subjects at Nogosari 1 Public High School. The results showed that from all assessments of media developed according to the level of eligibility included in the category Very Eligible to use. The results of this study are also in line with the results of Melisa's research (2019) under the title Development of E-Learning Based Learning Media in the Subject Development of Students in the Department of Electronics Engineering Education, Makassar State University. The results showed that the development of instructional media in the subject of media expert 1 student development got a percentage of $97 \%$ declared very feasible. Media expert 2 obtained a percentage of $96 \%$ declared very feasible. The results of student trials in one-on-one trials obtaining a percentage of $91 \%$ were declared very feasible, the results of small group trials obtaining a percentage of $88 \%$ were stated to be very feasible and the results of the large group trials obtaining a percentage of $89 \%$ were declared to be very feasible. From the results of research on learning media development of students developed has a category of "very feasible" to be used or implemented in learning the development of students.

The results of this study are also in accordance with Mansur's research results [7] with the title Development of Google Classroom-Based Mobile Learning Media for Marketing Subjects Basic Competencies Implementing Product Promotion (Study in Class $\mathrm{X}$ Marketing at SMK Muhammadiyah 2 Malang). The results showed that based on the results of the validation of the two material experts reached an average of $96.67 \%$. The results of the validation of media experts get an average of $95.56 \%$ that states the learning media of mobile learning based on Google classroom is very valid and worth testing. The results of student responses at the stage of field trials resulted in 
an average percentage of $94.41 \%$ that states that the learning media for mobile learning is appropriate.

\section{Conclusions and Suggestions}

\section{Conclusion}

Based on the results of this study can be concluded:

1. Google Classroom Based Learning Media for Patisserie Subject according to material experts include good categories with a value of $82.86 \%$.

2. Google Classroom Based Learning Media for Patisserie Subject according to media experts include very good category with a value of $92.5 \%$.

3. Google Classroom Based Learning Media for Patisserie Subject according to users, include good category with an average of $86.82 \%$.

\section{Suggestion}

Based on the results of this study it can be suggested:

1. It is recommended that every lecturer use the google classroom learning media in teaching and learning activities in the classroom.

2. Google Classroom can be used by students as the independent learning media.

\section{Acknowledgement}

The author would like to thank LPPM Unimed for funding this research. Thank you also to the validation experts and the users, who have helped carry out this research, as well as all those who have supported the implementation of this research.

\section{References}

[1] Sadiman A, dkk. Educational Media: Understanding, Development and Utilization. Depok: PT. Raja Grafindo Persada (2016).

[2] Nissen, Jayson et al.. A Comparison of Hake's $g$ and Cohen's d for Analyzing Gain on Concept Inventories. Journal Physics Education (2016)

[3] Hardyanto, R. Hafid. Development and Implementation of E-learning Using Moodle and Vicon for Web Programming Lessons in Vocational Schools. Journal of Vocational Education. Vol 6 No 1. (2016).

[4] Marasmita D. Development of E-Learning Media Based on Google Classroom to Improve Student Learning Motivation in Economic Subjects in students ten grades in SMA Negeri 1 Nogosari. Accessed on August 6, (2019).

[5] Melisa I. Development of E-Learning Based Learning Media in the Subject of Student Development in Department of Electronics Engineering Education Universitas Negeri 
Makassar. Accessed on August 6,(2019).

[6] Wulansari E. Development of Learning Tools Based on Blended Learning Models by Utilizing Google Classroom on Vector Material in 3D Space in Students Ten Grades MIA 4 SMA Negeri 7 Yogyakarta. Accessed on August 6, (2019)

[7] Hidayat M. Development of Mobile Learning Media Based on Google Classroom for Marketing Subjects Basic Competencies Implementing Study Product Promotion in Students Ten Grades of Marketing SMK Muhammadiyah 2 Malang. Accessed on August $6,(2019)$. 